\title{
Healthy drinks made from okra and green tea extract for reducing blood cholesterol
}

\author{
*Cornelia, M. and Anggraini, M. \\ Department of Food Technology, Faculty of Science and Technology, Pelita Harapan University, UPH \\ Tower, B Building, Karawaci, Tangerang 15811, Indonesia
}

\begin{abstract}
Article history:
Received: 18 September 2019

Received in revised form: 15

October 2019

Accepted: 15 October 2019

Available Online: 29 October 2019
\end{abstract}

Keywords:

Antioxidant activity,

Beverages,

Cholesterol,

Green tea,

Okra seeds

DOI:

https://doi.org/10.26656/fr.2017.4(2).315

\begin{abstract}
Okra (Abelmoschus esculentus L.) seeds and green tea (Camellia sinensis) have been known have many beneficial functions for human's health, because of the high antioxidant contents and anti-cholesterol activities that can prevent cardiovascular disease. This research is aimed to make the formulation of healthy drink from okra seed juice with the addition of green tea extract. Green tea used was selected from green tea that has the best antioxidant activity from ten samples of green tea in the market. The best antioxidant activity data was found in Jawa tea extract with $\mathrm{IC}_{50} 85.28 \pm 0.21 \mu \mathrm{g} / \mathrm{mL}$ which was formulated with the extract of okra seeds, made in the ratio of 1: 4. Selected healthy drinks were tested for physical characteristics, antioxidant activities, and sensory tests, and have antioxidant activity $\mathrm{IC}_{50} 222.16 \pm 1.38 \mu \mathrm{g} / \mathrm{mL}$. Further research was to analyze the potential of drinks in reducing cholesterol in vitro and in vivo ways. In vitro, 500 ppm drinks were able to inhibit cholesterol up to $47.55 \pm 0.76 \%$ and in vivo, there was a significant decrease in cholesterol levels after drink for 21 days with cholesterol reduction to $35.50 \pm 2.37 \%$, triglycerides decrease $19.39 \pm 3.10 \%$, LDL decrease $34.76 \pm 2.62 \%$, and an increase of HDL to $94.74 \pm 16.53 \%$.
\end{abstract}

\section{Introduction}

Okra plant was a kind of plant that has many benefits, and almost all parts of the plant such as leaves, flowers, stalks, fruit and seed which could be processed into food products. Okra seeds have high protein content that can give hypocholesterolemic effects on various food products, and also contain high levels of flavonols $( \pm 3.4 \mathrm{mg} / \mathrm{g})$ as one of ingredients with a high phenolic component. The high phenolic content makes okra seeds have the ability as antioxidants, anti-inflammatory and also anti-microbial. Even though there were several other health benefits, the utilization of Okra seeds in Indonesia was still infrequent and still need to be explored (Dhruve et al., 2015). Green tea (Camellia sinensis) was also known as refreshment ingredients that were commonly used in various foods and beverages. Green tea was also known for its high polyphenols content. The polyphenols contained in green tea include flavanol, hydroxyl-4flavanol, flavones, flavonoids, flavandiols and also phenolic acids. These polyphenols contribute at least up to $30 \%$ of the dry weight of tea leaves and have a good contribution to human health which able to increase HDL levels in the blood that makes it good for preventing free radicals and preventing various kinds of diseases such as cholesterol. Green tea could be easily obtained and liked by the people for its aromas and flavors that give a calming effect. This research aimed to utilize Okra seeds and extract green tea that will be formulated into beverage that can reduce blood's cholesterol (analysis in vitro and in vivo).

\section{Materials and methods}

\subsection{Materials and equipment}

The materials had been used in this research were green okra and green tea. Green okra from a farm located in Serpong, Tangerang which also had been identified by the Indonesian Institute of Sciences. Green tea were bought from commercial market with local and imported brands. Chemical reagents used were ethanol $70 \%$, glucose, flavoring, ethanol 96\%, cholesterol powder (Sigma), cholic acid (Sigma), DPPH, methanol, acetic acid anhydrate, $\mathrm{K}_{2} \mathrm{SO}_{4}$, selenium, $\mathrm{H}_{2} \mathrm{O}_{2}, \mathrm{H}_{2} \mathrm{SO}_{4}, \mathrm{NaOH}$ $35 \%, \mathrm{H}_{3} \mathrm{BO}_{3}, \mathrm{HCl} 0.2 \mathrm{~N}$, brom cherosol green-methyl red indicator and petroleum ether. In vivo method was using cholesterol kit, triglyceride kit, HDL kit, and LDL kit (Dyasis). Equipment used in the research such as UVVis spectrophotometer, chromameter, $\mathrm{pH}$ meter, hand refractometer, Kjeldahl flask, separating funnel, oven, heater, analytical balance, filter cloth, blender. 


\subsection{Methods}

This research was conducted into three stages where on stage I determination of the best green tea extract. On stage II, determination of okra seed's juice with several solvent ratios. On research stage III, the chosen beverage formulated using the chosen green tea extract and okra seed's juice would be tested in reducing blood's cholesterol with in vitro and in vivo method.

\subsubsection{Research stage I}

Determination of green tea extract was done using 10 (ten) green tea brands samples (purposive random sampling method) that can be found in the market. There were 5 local brands of green tea that were used Sosro Tea, Jawa Tea, 2 Tang Tea, Tong Tji Tea, and Cap Botol Tea. Also, another 5 imported brands of green tea also used Lipton Tea, Ahmad Tea, Twinning Tea, Dilmah Tea, and Japanese Tea. All those green teas were extracted using the best extraction method as mentioned in the research procedures (Shabri and Rohdiana, 2016). Green tea was extracted using ethanol $70 \%$ in the ratio of $1: 15(\mathrm{w} / \mathrm{v})$ for $15 \mathrm{mins}$ on $60^{\circ} \mathrm{C}$. After the extraction time completed, that mixture was filtered using filter cloth 230 mesh and evaporated using rotary evaporator until the aqueous extract was obtained. The yield of extract would be calculated while the antioxidant activity of the obtained extract also determined through DPPH method (Chaturvedula and Prakash, 2011).

\subsubsection{Research stage II}

Okra seed's juice was made in three ratios of water as solvent, 1:3, 1:4, and 1:5. Okra seeds were removed from the fruit and cleaned using mineral water. After that, weighing the seeds and addition of aquadest was done according to the solvent ratio followed by the crushing process using the blender. Those mixtures were boiled for $\pm 10 \mathrm{~min}$ and filtered by filter cloth. The obtained juice will be tested for physical characteristic as color, $\mathrm{pH}$, total dissolved solids, sensory test (scoring and hedonic), and the antioxidant activity with DPPH method (Molyneux, 2004).

\subsubsection{Research stage III}

The chosen green tea extract and Okra seed's juice from the previous stage were formulated into the beverage, and be tested for physical characteristic, sensory test, antioxidant activity, and also the potential of the beverages in reducing blood's cholesterol. Okra seed's juice was mixed with green tea extract, glucose, and flavoring (mint) in accordance with the established formulation. Beverage's potential in reducing blood's cholesterol was done with in vitro and in vivo method. In vitro testing was done photometrical based on the
Lieberman-Burchard reaction (Attarde et al., 2010). Beverage's sample was made into 5 series of concentrations (100-500 ppm) that was done by dissolving the beverage's sample with ethanol $96 \%$ and was measured its absorbance (Hilmi et al., 2014). In vivo method was done in 5 weeks with a habituation period of 7 days followed by cholesterol induction for 7 days, and treatment for 21 days. There were 4 groups of treatment (normal, positive (hyper cholesterol), negative (drugs of choice/Simvastatin), and product). Cholesterol induction was done by mixing $10 \mathrm{~g}$ of cholesterol powder and $2 \mathrm{~g}$ of cholic acid of standard food as mentioned in AIN93M (Malole and Pramono, 1989). On day 0 and 21 after treatment was given, blood sampling was done by taking $1.5 \mathrm{~mL}$ blood from sinus orbitalis using Ketamine 60 $\mathrm{mg} / \mathrm{kg}$ weight as anesthesia through intra-muscular that used for determining lipid profile including total cholesterol, triglyceride, HDL, and LDL (Purnamaningsih, 2001).

\section{Results and discussion}

\subsection{Determination the best antioxidant activity of green tea extract}

The yield and antioxidant activity from ten brands green tea extracts were analyzed. The yield of green tea extracts can be seen in Table 1. Statistical analysis that had been done indicating that different sample of green tea extract was giving significant $(p<0.05)$ effect to the yield obtained. Green tea extract from Lipton Tea has the highest yield among the ten other green tea brands $(7.98+0.15 \%)$. Antioxidant activity (as $\mathrm{IC}_{50}$ value) that was obtained from the ten samples of green tea extracts showed a significant $(\mathrm{p}<0.05)$ results between the samples. Highest antioxidant activity (the lowest $\mathrm{IC}_{50}$ value) was obtained from Jawa Tea with an $\mathrm{IC}_{50}$ value of $85.28+0.21 \mu \mathrm{g} / \mathrm{mL}$. The lower $\mathrm{IC}_{50}$ value would show better antioxidant activity (Molyneux, 2004). Green tea extract that was made using Jawa tea has a strong antioxidant activity where the value $\mathrm{IC}_{50}$ obtained is in the range of 50 up to $100 \mu \mathrm{g} / \mathrm{mL}$ (Sharma et al., 2007). When the value of $\mathrm{IC}_{50}$ obtained is below $50 \mu \mathrm{g} / \mathrm{mL}$, the sample is having a very strong antioxidant activity, while the value of $\mathrm{IC}_{50}$ obtained is higher than $100 \mu \mathrm{g} / \mathrm{mL}$, the sample has weak antioxidant activity. The results of antioxidant activity on green tea extracts can be seen in Table 1 . Based on antioxidant activity analysis and the yield obtained that had been done, it could be concluded that the best extract was shown by Jawa Tea. Jawa Tea produced green tea extract with the best antioxidant activity among all with a high yield obtained. Even the yield of the Jawa Tea was not as high of the Lipton Tea and the price of Jawa Tea also becomes another consideration when the price of Jawa Tea is inexpensive. With the affordable price, Jawa Tea has the best option 
produced the best green tea extract and it would be used in the next research stage with relatively high yield and antioxidant activity.

Table 1. \%Yield and antioxidant activity of green tea extracts

\begin{tabular}{lcc}
\hline $\begin{array}{c}\text { Brands of Green Tea } \\
\text { Sample }\end{array}$ & Yield (\%) & $\begin{array}{c}\text { Antioxidant Activity } \\
\mathrm{IC}_{50}(\mu \mathrm{g} / \mathrm{mL})\end{array}$ \\
\hline Tong Tji & $4.17 \pm 0.03^{\mathrm{a}}$ & $261.21 \pm 0.27^{\mathrm{g}}$ \\
Dilmah & $4.38 \pm 0.15^{\mathrm{a}}$ & $335.58 \pm 4.03^{\mathrm{i}}$ \\
Japanese & $5.20 \pm 0.03^{\mathrm{b}}$ & $247.61 \pm 3.38^{\mathrm{f}}$ \\
Twinning & $5.74 \pm 0.05^{\mathrm{c}}$ & $286.36 \pm 3.97^{\mathrm{h}}$ \\
Cap Botol & $6.02 \pm 0.06^{\mathrm{c}}$ & $218.09 \pm 0.98^{\mathrm{d}}$ \\
Sosro & $6.43 \pm 0.11^{\mathrm{d}}$ & $245.67 \pm 3.74^{\mathrm{f}}$ \\
2 Tang & $7.00 \pm 0.04^{\mathrm{e}}$ & $107.03 \pm 1.21^{\mathrm{b}}$ \\
Ahmad & $7.08 \pm 0.10^{\mathrm{e}}$ & $238.27 \pm 0.99^{\mathrm{e}}$ \\
Jawa & $7.22 \pm 0.16^{\mathrm{e}}$ & $85.28 \pm 0.21^{\mathrm{a}}$ \\
Lipton & $7.98 \pm 0.15^{\mathrm{f}}$ & $172.70 \pm 1.75^{\mathrm{c}}$ \\
\hline
\end{tabular}

Values are expressed as mean \pm SD. Different superscript within column indicates significant difference at $\mathrm{p}<0.05$.

\subsection{Determination of okra seed's juice}

Okra seed's juice was made by solvents (aquadest) ratio $1: 3,1: 4$, and 1:5 (w/v). Then, okra seed's juice was analyzed for the physical characteristic (color, $\mathrm{pH}$, and total dissolved solids), sensory test (scoring and hedonic), also antioxidant activity analysis. The physical characteristic of the samples can be seen in Table 2. The three samples obtained have a similar color to each other which is reddish yellow (Dhruve et al., 2015). For $\mathrm{pH}$ value, there were not a significant $(p>0.05)$ results between those three-sample obtained. All the samples have similar $\mathrm{pH}$ value of 6.15 . Total dissolved solids from three different ratios of solvents produced a significant result $(\mathrm{p}<0.05)$ between those samples. Higher amount of solvents used will cause the decreasing of the concentration of okra seed's juice that would also decrease the number of total dissolved solids. The results of antioxidant activity measurements can be seen in Table 3. There were a significant $(p<0.05)$ difference of antioxidant activity obtained from three ratios of the number of solvents used in the making of okra seed's juice. The best antioxidant activity obtained by okra seed's juice that was made using the solvent with the ratio of 1:3. All those ratios of the number of solvents used in the making of okra seed's juice would produce okra seed's juice that had the potency as antioxidant substances with the value of $\mathrm{IC}_{50}$ between 200 up to $1000 \mu \mathrm{g} / \mathrm{mL}$. However, when the value of $\mathrm{IC}_{50}$ obtained are in the range of 200 up to $1000 \mu \mathrm{g} / \mathrm{mL}$, the sample used still can be stated with less active antioxidant activity with the potency as antioxidant substances (Mukhopadhyay, 2006).

In the end, okra seed's juice that was made with the number of solvent ratio of 1:4 was chosen as the best okra seed's juice based on consumer acceptance that was better and the number of antioxidant activity that was pretty well between the other two samples (Kumar et al., 2013). The results of the analysis of the chosen okra seed's juice are shown in Table 4. Sensory test conducted includes scoring and hedonic test. The result of the color test showed that okra seed's juice that was made with the ratio of solvent 1:3 would produce juice with the color of rather dark green while 1:4 and 1:5 would produce juice with the color of rather light green. The scoring test of foreign aroma on the samples showed that all samples had produced rather not felt foreign aroma. For foreign flavor, juices from 1:3 ratio producing rather felt foreign flavor, while 1:4 and 1:5 producing juice with rather not felt foreign flavor. Hedonic test that had been conducted showed that color, aroma, and flavor of all samples are neutrally accepted even though overall, juice that was made with the ratio of $1: 4$ and 1:5 were more likely to be accepted significantly $(p<0.05)$ than the juice made with the ratio of 1:3. The best Okra seed's juice was determined through considering physical characteristic, sensory characteristic, and antioxidant activity analysis from all the samples obtained.

Table 2. Okra seed's juice physical characteristics

\begin{tabular}{cccc}
\hline $\begin{array}{c}\text { Sample's } \\
\text { Ratio }\end{array}$ & $\begin{array}{c}\text { Color } \\
\left({ }^{\circ} \mathrm{Hue}\right)\end{array}$ & $\mathrm{pH}$ & $\begin{array}{c}\text { Total Dissolved Solids } \\
\left({ }^{\circ} \text { Brix }\right)\end{array}$ \\
\hline Okra 1:3 & $83.46 \pm 0.41$ & $6.15 \pm 0.02^{\mathrm{a}}$ & $9.70 \pm 0.11^{\mathrm{c}}$ \\
Okra 1:4 & $86.21 \pm 0.95$ & $6.15 \pm 0.03^{\mathrm{a}}$ & $9.26 \pm 0.17^{\mathrm{b}}$ \\
Okra 1:5 & $87.40 \pm 0.22$ & $6.15 \pm 0.01^{\mathrm{a}}$ & $8.10 \pm 0.11^{\mathrm{a}}$ \\
\hline
\end{tabular}

Values are expressed as mean \pm SD. Different superscript within column indicates significant difference at $\mathrm{p}<0.05$.

Table 3. Antioxidant activity of okra seed's juice

\begin{tabular}{cc}
\hline Samples & $\mathrm{IC}_{50}(\mu \mathrm{g} / \mathrm{mL})$ \\
\hline Okra 1:3 & $552.38 \pm 5.50^{\mathrm{a}}$ \\
Okra 1:4 & $569.55 \pm 0.34^{\mathrm{b}}$ \\
Okra 1:5 & $668.37 \pm 0.90^{\mathrm{c}}$ \\
\hline
\end{tabular}

Values are expressed as mean \pm SD. Different superscript within column indicates significant difference at $p<0.05$.

Table 4. Analysis of best (chosen) okra seed's juice

\begin{tabular}{llc}
\hline Characteristic & & Results \\
\hline Antioxidant activity $(\mu \mathrm{g} / \mathrm{mL})$ & 569 \\
Physical & Color $\left({ }^{\circ} \mathrm{Hue}\right)$ & 86.21 \\
& $\mathrm{pH}$ & 6.15 \\
\multirow{4}{*}{ Sensory Scoring } & Total Dissolved Solid $\left({ }^{\circ}\right.$ Brix $)$ & 9.26 \\
& Color & 3.3 \\
& Foreign Aroma & 3.69 \\
Hedonic & Foreign Flavor & 3.22 \\
& Color & 3.21 \\
& Aroma & 3.04 \\
& Flavor & 2.91 \\
& Overall & 3.2 \\
\hline
\end{tabular}




\subsection{Beverage's potential to reducing cholesterol}

Green tea extract from Jawa Tea was used in the beverage's formulation along with Okra seed's juice that was made with the solvent ratio of 1:4. The formulated beverage will be analyzed for its physical characteristic, sensory, and antioxidant activity as shown in Table 5. The further test was a potential study on reducing blood's cholesterol was conducted with in vitro and in vivo method. In vitro test on reducing blood's cholesterol was done in 5 series of beverage's concentration $(100,200,300,400$, and $500 \mathrm{ppm})$ showed results as shown in Table 6 . There are significantly $(p<0.05)$ increased the number of cholesterol inhibition along with the increasing number of beverage's concentration (Hilmi et al., 2014). On 500 ppm, cholesterol could be inhibited up to $47.55 \%$. The results indicated that there was potency in reducing blood's cholesterol from the beverage that was formulated in the research. Analysis of beverage's potency in reducing blood's cholesterol with the in vivo method showed that by giving the treatment of product as much as $2 \mathrm{~mL} / 200$ $\mathrm{g}$ /day for 21 days can reduce the number of total cholesterol, triglyceride, LDL, and increasing number of HDL in blood (Attarde et al., 2010). The results of the test that was conducted with the in vivo method can be seen in Figure 1 for total cholesterol, Figure 2 for triglyceride, Figure 3 for HDL, and Figure 4 for LDL. Based on the data that were obtained, there were significant $(p<0.05)$ differences in the value of total cholesterol, triglyceride, HDL, and LDL between product treatment between other treatment. Moreover, there was a decreasing number of total cholesterol number, triglyceride, and LDL, and an increasing number of HDL along with the treatment using the formulated product. Besides the significant differences that could be found on four parameters that were tested as lipid profile parameters, the treatment by giving formulated beverage could improve the lipid profile into normal stage with the number of total cholesterol between 40 up to $130 \mathrm{mg} / \mathrm{dL}$, with the number of triglyceride between 26 up to $145 \mathrm{mg} / \mathrm{dL}$ (Shabri and Rohdiana, 2016).

Table 5. Beverage's characteristic

\begin{tabular}{lc}
\hline Characteristic & Value \\
\hline Color $\left({ }^{\circ} \mathrm{Hue}\right)$ & $87.44 \pm 0.51$ \\
$\mathrm{pH}$ & $5.81 \pm 0.01$ \\
Total Dissolved Solids $\left({ }^{\circ}\right.$ Brix $)$ & $16.50 \pm 0.10$ \\
$\mathrm{IC}_{50}(\mu \mathrm{g} / \mathrm{mL})$ & $222.02 \pm 1.18$ \\
Overall Hedonic & $3.43 \pm 0.63$ \\
\hline
\end{tabular}

Even there were significant improvements in the lipid profile; the formulated beverage still couldn't give effect as good as the effect obtained using the commercial drug, Simvastatin. There were significant differences in reducing number of total cholesterol, triglyceride, and LDL value between the group that were given beverage treatment and the group that were given the Simvastatin. However, there wasn't any significant difference in the increasing number of HDL on those two groups. The formulated beverage had the ability in improving blood's lipid profile on the dosage of $112 \mathrm{ml} /$ days for the human being. The comparison between those two groups can be seen in Figure 5. The formulated beverage contains flavonoid substances that were contributed from the Okra seeds and green tea extract that were fortified in the formulated beverage. Flavonoid can have acted as anti-hypercholesterolemia substances by reducing LDL in the body (Purnamaningsih et al., 2001) through the mechanism that was similar done by anti-hyperlipidemia drugs from statin group with the mechanism as the inhibitor of HMG Co-A reductase (Attarde et al., 2010). The inhibition of HMG Co-A reductase will inhibit the production of mevalonate so that the process of producing cholesterol in the blood will be inhibited as well (Attarde et al., 2010). Another component that also contained by the formulated beverage is polyphenol. Okra seed was a food material that contains a high number of unsaturated fatty acid. At least, $47.4 \%$ of all the lipid contains in the Okra seed was made up of linoleic acid (Dhruve et al., 2015). Saturated fatty acid acts as a precursor in the making of cholesterol in the blood that will increase the number of total cholesterol and reducing the number of HDL in the blood. In the other side, the unsaturated fatty acid has the opposite mechanism to saturated fatty acid so that the value of HDL in the blood can be increased and the risk of getting arteriosclerosis can be prevented (Purnamaningsih et al., 2001).

\begin{tabular}{llc}
\multicolumn{2}{l}{ Table 6. Results of in vitro method } \\
\hline No Sample & $\%$ inhibition \\
\hline 1 & Negative control (cholesterol $100 \mathrm{ppm})$ & --- \\
2 & Negative control + sample $100 \mathrm{ppm}$ & 9.87 \\
3 & Negative control + sample $200 \mathrm{ppm}$ & 16.63 \\
4 & Negative control + sample $300 \mathrm{ppm}$ & 25.49 \\
5 & Negative control + sample $400 \mathrm{ppm}$ & 37.53 \\
6 & Negative control + sample $500 \mathrm{ppm}$ & 47.55 \\
\hline
\end{tabular}

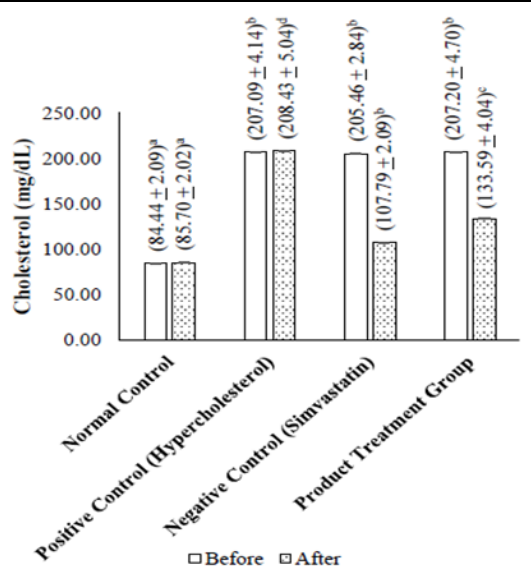

Figure 1. Test results on cholesterol. Different alphabets above bars indicate significant difference $(p<0.05)$ between groups.

C 2019 The Authors. Published by Rynnye Lyan Resources 


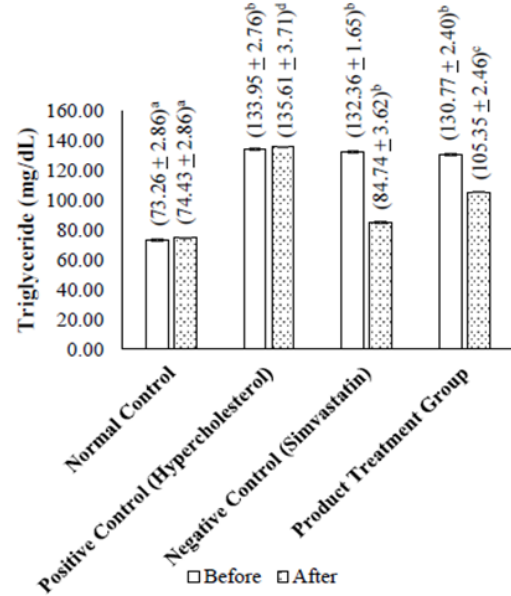

Figure 2. Test results on triglyceride. Different alphabets above bars indicate significant difference $(p<0.05)$ between groups.

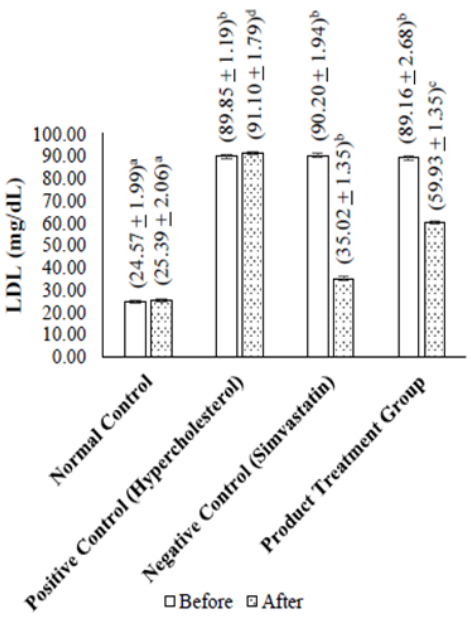

Figure 4. Test results on LDL. Different alphabets above bars indicate significant difference $(\mathrm{p}<0.05)$ between groups.

\section{Conclusion}

The chosen Okra seed's juice was made by the solvent (aquadest) ratio of 1:4 has $\mathrm{IC}_{50} 569 \pm 0.34 \mu \mathrm{g} / \mathrm{mL}$. The chosen green tea extract was made with Jawa Tea which has $\mathrm{IC}_{50} 85.28 \pm 0.21 \mu \mathrm{g} / \mathrm{mL}$. The chosen green tea extract can be said to have a strong antioxidant activity where the $\mathrm{IC}_{50}$ value obtained is between 50 to $100 \mu \mathrm{g} /$ $\mathrm{mL}$. The formulation of beverage was made with the adding of $15 \mathrm{~mL}$ green tea extract fin every $100 \mathrm{~mL}$ Okra seed's juice, with the addition of $10 \mathrm{~g}$ glucose and $1 \mathrm{~mL}$ flavoring (mint) have $\mathrm{IC}_{50} 222.16 \pm 1.38 \mu \mathrm{g} / \mathrm{mL}$. The addition of the flavoring didn't give any significant differences in antioxidant activity value $(\mathrm{p}>0.05)$. $\mathrm{IC}_{50}$ values that are found to be in the range of 200 to 1000 $\mu \mathrm{g} / \mathrm{mL}$ can be said to have less active antioxidant activity but there is still potential as an antioxidant compound. In vitro method showed that $47.55 \pm 0.76 \%$ of cholesterol could be inhibited with the concentration of the sample by $500 \mathrm{ppm}$. In vivo method showed that by giving the formulated beverage $2 \mathrm{~mL} / 200 \mathrm{~g}$ /days for 21 days significantly $(\mathrm{p}>0.05)$ reducing cholesterol up to $35.50 \pm 2.37 \%$, triglyceride $19.39 \pm 3.10 \%$, LDL

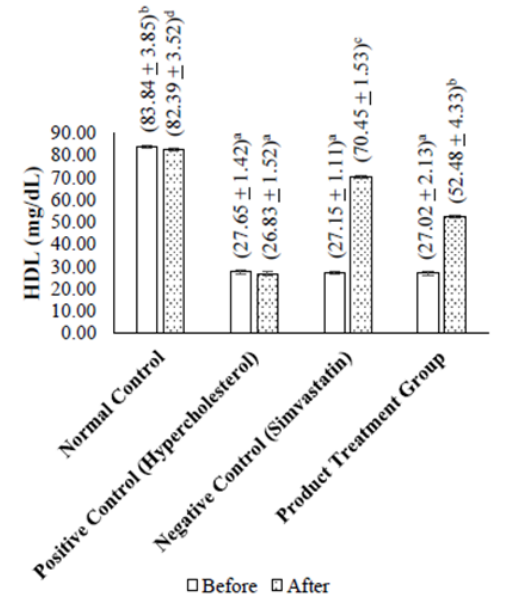

Figure 3. Test results on HDL. Different alphabets above bars indicate significant difference $(\mathrm{p}<0.05)$ between groups.

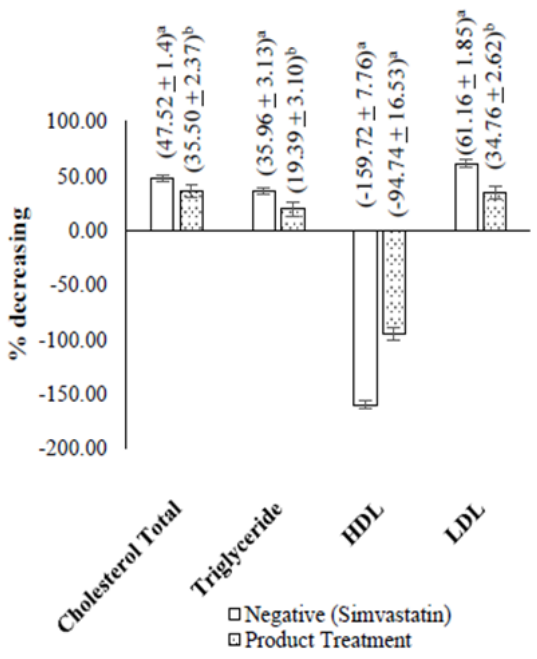

Figure 5. Comparison of in vivo results. Different alphabets above bars indicate significant difference $(p<0.05)$ between groups.

$34.76 \pm 2.62 \%$, and increasing HDL up to $94.74 \pm 16.53 \%$. However, the effect gained by using the formulated beverage still couldn't be as good as using the commercial drug, Simvastatin. With the protein content of $0.45 \%$, lipid $0.56 \%$, ash $0.14 \%$, carbohydrate $15.88 \%$, and water content in the amount of $82.98 \%$, the formulated beverage could be categorized as functional beverages because of the significant effect on reducing blood's cholesterol.

\section{Conflict of Interest}

The authors declare no conflict of interest.

\section{References}

Attarde, D., Pawar, J., Chaudari, B. and Pal, S. (2010). Estimation of Sterol Content in Edible Oil and Ghee Samples. International Journal of Pharmaceutical Sciences Review and Research, 5(1), 135-137.

Chaturvedula, V.S.P. and Prakash, I. (2011). The Aroma, Taste, Color and Bioactive Constituents of Tea. 
Journal of Medicinal Plants Research, 5(11), 21102124.

Dhruve, J.J., Shukla, Y.M., Shah, R., Patel, J. and Talati, J.G. (2015). Contribution of Okra (Abelmoschus esculentus L.) Seeds Towards the Nutritional Characterization. World Journal of Pharmacy and Pharmaceutical Sciences, 4(7), 1009-1023.

Hilmi, Y., Abushama, M.F., Abdalgadir, H., Khalid, A. and Khalid, H. (2014). A Study of Antioxidant Activity, Enzymatic Inhibition and In Vitro Toxicity of Selected Traditional Sudanese Plants with Antidiabetic Potential. BMC Complementary and Alternative Medicine, 14, 1-5. https:// doi.org/10.1186/1472-6882-14-149

Kumar, D. S., Tony, D.E., Kumar, A.P., Kumar, K.A., Rao, D.B.S. and Nadendla, R. (2013). A Review On Abelmoschus Esculentus (Okra). International Research Journal of Pharmaceutical and Applied Sciences, 3(4), 129-132.

Malole, M. B. M. and Pramono, U.S.C. (1989). Penggunaan Hewan-Hewan Percobaan di Laboratorium. Bogor: Pusat Antar Universitas, Institut Pertanian Bogor. [In Bahasa Indonesia].

Molyneux, P. (2004). The Use of The Stable Free Radical Diphenylpicrylhydrazyl (DPPH) for Estimating Antioxidant Activity. Songklanakarin Journal of Science Technology, 26(2), 211-219.

Mukhopadhyay, A.K. (2006). Antioxidants: Natural and Synthetic. Kiel, Germany: Amani International Publishers.

Purnamaningsih, H., Wuryastuti, H. and Raharjo, S. (2001). Pengaruh pemberian ransum tinggi cholesterol dan/ atau tinggi lemak terhadap cholesterol plasma pada tikus Spraque-Dawley. Universitas Gajah Mada, Yogyakarta. [In Bahasa Indonesia].

Shabri and Rohdiana, D. (2016). Optimasi dan Karakterisasi Ekstrak Polifenol Teh Hijau dari Berbagai pelarut. Jurnal Penelitian Teh dan Kina, 2016, 57-66. [In Bahasa Indonesia].

Sharma, V.K., Bhattacharya, A., Kumar, A. and Sharma, H.K. (2007). Health Benefits of Tea Consumption. Tropical Journal of Pharmaceutical Research, 6(3), 785-792. https://doi.org/10.4314/tjpr.v6i3.14660 